\title{
Assessment of Emaciation in Relation to Threat to Life in Anorexia Nervosa
}

\author{
Kenjiro OKABE
}

\begin{abstract}
Twenty patients with anorexia nervosa and a body weight below $60 \%$ of the standard weight were studied. One died of starvation; the others survived. Four patients, including the deceased, had such severe weakness that they could not sit up without support, and another five could sit up only from a lateral position. Serum albumin or hemoglobin levels at the beginning of therapy could not be used for nutritional assessment because of dehydration, while increased blood urea nitrogen was associated with acute illness. The present results together with data from previous studies of fatal anorexia indicate that the risk of mortality may be quite low when body weight is above $60 \%$ of the standard. We suggest that gross muscle weakness in addition to body weight for height can be a valuable indicator to assess the criticalness in anorexia nervosa.

(Internal Medicine 32: 837-842, 1993)
\end{abstract}

Key words: starvation, weight loss, mortality, weakness

\section{Introduction}

Anorexia nervosa is a potentially fatal illness, with the reported mortality rate ranging from $4 \%$ or less (1) to $18 \%$ (2). Starvation along with its complications is the most common cause of death, and Schwartz and Thompson (3) have estimated that the mortality rate from self-starvation is $6 \%$. In contrast to the many reports of death from starvation in anorexia nervosa, there have been few previous reports regarding the degree of emaciation that is potentially life-threatening. Some patients with anorexia nervosa do not visit the hospital until their physical condition is disordered. Physical and biological abnormalities in anorexia nervosa are usually reversed only by weight gain. Proper management in the acute phase is important, and some guidelines for assessment of criticalness in clinical settings are required. Here, we discuss the degree of emaciation that is life-threatening and the findings useful in assessing criticalness.

\section{Subjects and Methods}

Twenty patients (18 females and 2 males) with anorexia nervosa fulfilling DSM-III-R (Diagnostic and Statistical Manual of Mental Disorders, Third Edition, Revised) criteria whose body weight was below $60 \%$ of standard weight (4) on admission were studied. Five patients had bulimia with episodes of vomiting. Patient characteristics are summarized in Table 1.
Physical and laboratory examinations were undertaken at the outset of therapy; most were conducted on admission, but some had been conducted at the time of first contact for patients who were admitted several days or weeks later. An electrocardiogram was taken during the first week of admission in all patients except the deceased. Laboratory investigations were repeated during the fourth week in 12 patients.

\section{Results}

One patient (Patient 7) died of starvation. She was admitted on the day of first contact and received $500 \mathrm{ml}$ of $5 \%$ dextrose in Ringer's lactate. Thereafter, she rejected further fluid administration. In the early morning of the third day after admission insidious cardiac arrest occurred and resuscitation failed. Her lowest body weight was $25 \mathrm{~kg}$. Autopsy was not performed. Another patient (Patient 1) developed hypoglycemic coma followed by pneumonia and then recovered. The remaining 18 patients survived without serious physical complications.

The physical findings of the 20 patients at the outset of therapy are shown in Table 2. Pulse rate was 60 per minute or lower in 15 patients. Systolic blood pressure was below 80 $\mathrm{mmHg}$ in 5 patients. In 7 of 12 patients, pulse rate increased by more than 30 beats per minute upon changing from the supine to the standing position (orthostatic tachycardia). Four patients, including the deceased, had such severe weakness that they could not sit up from supine position without support. Six could

From the Department of Psychosomatic Medicine, Tenri Hospital, Nara

Received for publication February 5, 1993; Accepted for publication October 26, 1993

Reprint requests should be addressed to Dr. Kenjiro Okabe, the Department of Psychosomatic Medicine, Tenri Hospital, 200 Mishima, Tenri, Nara 632 
Окаве

Table 1. Patient Characteristics

\begin{tabular}{ccccccccc}
\hline $\begin{array}{c}\text { Patient } \\
\text { No. }\end{array}$ & $\begin{array}{c}\text { Age } \\
\text { (yr) }\end{array}$ & Sex & $\begin{array}{c}\text { Height } \\
(\mathrm{cm})\end{array}$ & $\begin{array}{c}\text { Weight } \\
(\mathrm{kg})\end{array}$ & $\begin{array}{c}\text { Percentage } \\
\text { of standard } \\
\text { weight }\end{array}$ & $\begin{array}{c}\text { Percentage } \\
\text { of weight } \\
\text { change }\end{array}$ & $\begin{array}{c}\text { Duration } \\
\text { of illness } \\
(\mathrm{yr})\end{array}$ & Vomiting \\
\hline 1 & 17 & F & 158 & 21 & 38.3 & 50 & 2.0 & - \\
2 & 19 & F & 163 & 25 & 42.9 & 51 & 3.2 & - \\
3 & 16 & F & 157 & 25 & 46.0 & 47 & 1.2 & - \\
4 & 17 & F & 165 & 28 & 47.1 & 30 & 0.7 & - \\
5 & 22 & F & 164 & 29 & 49.2 & 47 & 1.8 & - \\
6 & 25 & F & 154 & 26 & 49.5 & 48 & 5.0 & - \\
$7 *$ & 16 & F & 156 & 27 & 50.3 & 40 & 0.7 & - \\
8 & 22 & F & 156 & 27 & 50.3 & 51 & 5.0 & - \\
9 & 16 & M & 165 & 32 & 50.4 & 47 & 0.3 & - \\
10 & 23 & F & 162 & 30 & 52.1 & 57 & 2.0 & + \\
11 & 21 & F & 150 & 27 & 53.6 & 29 & 2.3 & - \\
12 & 17 & F & 156 & 29 & 54.0 & 38 & 2.7 & + \\
13 & 18 & F & 156 & 29 & 54.0 & 44 & 1.8 & - \\
14 & 29 & F & 155 & 29 & 54.6 & 33 & 3.0 & + \\
15 & 16 & M & 173 & 38 & 55.3 & 31 & 3.0 & - \\
16 & 33 & F & 152 & 29 & 56.3 & 40 & 4.0 & + \\
17 & 16 & F & 163 & 33 & 56.6 & 39 & 1.2 & - \\
18 & 18 & F & 164 & 34 & 57.7 & 36 & 0.4 & - \\
19 & 19 & F & 159 & 32 & 57.7 & 41 & 3.3 & - \\
20 & 20 & F & 159 & 32 & 57.7 & 36 & 1.0 & + \\
\hline
\end{tabular}

*died, ${ }^{\dagger}$ (original weight - weight at the beginning of therapy/original weight $) \times 100$.

Table 2. Physical Findings at the Beginning of Therapy

\begin{tabular}{cccccc}
\hline $\begin{array}{c}\text { Patient } \\
\text { No. }\end{array}$ & $\begin{array}{c}\text { Pulse } \\
\text { (beats } \\
\text { per min) }\end{array}$ & $\begin{array}{c}\text { Blood } \\
\text { pressure } \\
\text { (mmHg) }\end{array}$ & $\begin{array}{c}\text { Orthostatic } \\
\text { tachycardia }\end{array}$ & Weakness & $\begin{array}{c}\text { Petechia or } \\
\text { Ecchymosis }\end{array}$ \\
\hline 1 & 54 & $72 /$ palpable & + & ++ & + \\
2 & 50 & $94 / 72$ & NE & + & + \\
3 & 60 & $100 /$ palpable & NE & ++ & ++ \\
4 & 40 & $78 / 40$ & - & + & - \\
5 & 58 & $88 / 58$ & + & + & - \\
6 & 48 & $96 /$ palpable & + & + & + \\
$7 *$ & 42 & $88 / 70$ & NE & ++ & + \\
8 & 60 & $82 /$ palpable & - & + & - \\
9 & 40 & $90 / 60$ & NE & ++ & ++ \\
10 & 72 & $82 / 38$ & NE & - & - \\
11 & 48 & $94 / 68$ & - & - & - \\
12 & 66 & $84 / 60$ & - & - & - \\
13 & 58 & $108 / 76$ & + & - & - \\
14 & 66 & $76 / 38$ & NE & - & - \\
15 & 66 & $132 / 70$ & NE & - & + \\
16 & 66 & $74 / 30$ & NE & - & - \\
17 & 45 & $68 / 40$ & + & - & - \\
18 & 34 & $110 / 60$ & + & + & + \\
19 & 60 & $88 / 64$ & - & - & - \\
20 & 60 & $98 / 54$ & + & - & + \\
\hline
\end{tabular}

*died, NE: not examined.

sit up only from the lateral position, with head lag. The other 10 patients could sit up easily or by using their legs to propel their trunk upward. Muscle weakness subsided immediately after nutritional improvement. Nine had petechia or ecchymotic spots. Patients who had been undernourished over a long time were rather lively, but patients who had lost weight quickly (Patients 9 and 18) had gross muscle weakness in proportion to their weight loss. No patient had edema on admission, although 
Assessment of Emaciation in Anorexia

Table 3. Laboratory Findings at the Beginning of Therapy

\begin{tabular}{cccccrrr}
\hline $\begin{array}{c}\text { Patient } \\
\text { No. }\end{array}$ & $\begin{array}{c}\mathrm{BUN} \\
(\mathrm{mg} / \mathrm{dl})\end{array}$ & $\begin{array}{c}\text { Creatinine } \\
(\mathrm{mg} / \mathrm{dl})\end{array}$ & $\begin{array}{c}\mathrm{Na} \\
(\mathrm{mEq} / \mathrm{l})\end{array}$ & $\begin{array}{c}\mathrm{K} \\
(\mathrm{mEq} / \mathrm{l})\end{array}$ & $\begin{array}{c}\text { GOT } \\
(\mathrm{IU})\end{array}$ & $\begin{array}{c}\text { Albumin } \\
(\mathrm{g} / \mathrm{dl})\end{array}$ & $\begin{array}{c}\mathrm{Hb} \\
(\mathrm{g} / \mathrm{dl})\end{array}$ \\
\hline 1 & 72.8 & 1.0 & 141 & 4.3 & 519 & 4.1 & 12.9 \\
2 & 27.7 & 0.5 & 142 & 3.6 & 1025 & 4.3 & 10.1 \\
3 & 45.7 & 1.1 & 135 & 4.7 & 523 & 4.1 & 15.7 \\
4 & 30.8 & 1.1 & 138 & 3.9 & 180 & 3.9 & 11.3 \\
5 & 15.2 & 0.9 & 127 & 3.4 & 69 & 3.8 & 17.4 \\
6 & 49.3 & 1.1 & 138 & 5.0 & 86 & 4.0 & 15.4 \\
$7 *$ & 56.4 & 1.0 & 137 & 4.0 & 95 & 4.5 & 16.6 \\
8 & 15.4 & 0.7 & 141 & 4.4 & 44 & 4.1 & 12.5 \\
9 & 63.3 & 0.8 & 145 & 4.1 & 218 & 4.0 & 10.8 \\
10 & 20.0 & 0.8 & 138 & 3.8 & 15 & 4.1 & 11.6 \\
11 & 6.0 & 0.9 & 140 & 4.0 & 40 & 4.0 & 10.2 \\
12 & 10.8 & 0.8 & 139 & 2.8 & 32 & 4.0 & 17.8 \\
13 & 17.4 & 0.7 & $\mathrm{NE}$ & $\mathrm{NE}$ & 48 & 3.6 & 9.2 \\
14 & 14.0 & 0.7 & 140 & 3.8 & 31 & 3.2 & 10.9 \\
15 & 20.8 & 0.8 & 144 & 4.0 & 21 & 4.9 & 14.5 \\
16 & 17.7 & 1.8 & 141 & 3.2 & 29 & 4.1 & 11.0 \\
17 & 34.6 & 1.0 & 141 & 4.9 & 65 & 4.3 & 14.9 \\
18 & 32.9 & 1.1 & 136 & 5.1 & 46 & 4.5 & 14.5 \\
19 & 14.9 & 0.7 & 140 & 4.0 & 34 & 4.6 & 12.0 \\
20 & 33.9 & 1.0 & 143 & 4.3 & 14 & 4.0 & 10.7 \\
\hline
\end{tabular}

*died, NE: not examined.

some developed it during the course of therapy.

Laboratory findings of each patient at the outset of therapy are presented in Table 3. Blood urea nitrogen (BUN) levels exceeded $45 \mathrm{mg} / \mathrm{dl}$ in five patients, four of whom, including the deceased, had severe weakness. All patients in whom BUN levels exceeded $30 \mathrm{mg} / \mathrm{dl}$ had weakness and/or orthostatic tachycardia. Serum creatinine levels in all were almost within normal limits. Serum enzymes reflecting liver function were considerably increased in a few patients, but in several patients these values were within normal limits. Electrolyte balance was maintained in most patients, especially in restrictive anorexics. Patient 5 had hyponatremia due to diarrhea. Blood glucose at the initial examination was $30 \mathrm{mg} / \mathrm{ml}$ in Patient 2 and more than $50 \mathrm{mg} / \mathrm{dl}$ in all others.

Table 4 shows mean laboratory findings at the outset of therapy and at the fourth week after admission in 12 patients. Mean body weight increased from 27.7 to $31.1 \mathrm{~kg}$. BUN and GOT values nearly normalized, but serum albumin and hemoglobin concentration decreased.

Electrocardiograms showed $\mathrm{T}$ wave inversion or flattening in eight patients (Patients 2, 3, 4, 6, 10, 11, 16 and 17) and prolongation of QT interval corrected for heart rate in two patients (Patients 5 and 15). Low voltage was not observed in any patient. The finding of $\mathrm{T}$ wave inversion or flattening was not correlated with serum potassium level.

\section{Discussion}

Although numerous studies have delineated various measures of nutritional status that are related to increased morbidity and mortality $(5,6)$, most were conducted in surgical patients.
Table 4. Laboratory Findings and Weight at the Beginning of Therapy and at the Fourth Week after Admission

\begin{tabular}{lccccc}
\hline \multicolumn{1}{c}{ Time } & $\begin{array}{c}\text { Weight } \\
(\mathrm{kg})\end{array}$ & $\begin{array}{c}\text { BUN } \\
(\mathrm{mg} / \mathrm{dl})\end{array}$ & $\begin{array}{c}\text { GOT } \\
(\mathrm{IU})\end{array}$ & $\begin{array}{c}\text { Albumin } \\
(\mathrm{g} / \mathrm{dl})\end{array}$ & $\begin{array}{c}\mathrm{Hb} \\
(\mathrm{g} / \mathrm{dl})\end{array}$ \\
\hline Beginning of therapy* & 27.7 & 32.6 & 235 & 4.1 & 13.4 \\
Fourth week after admission* & 31.1 & 11.6 & 50 & 3.5 & 9.6 \\
\hline
\end{tabular}

Mean values are given. $* \mathrm{~N}=12$, Case Nos. $1,2,3,4,5,6,8,9,10,11,12$ and 17.

Patients with anorexia nervosa, especially if extremely emaciated, are often dehydrated. Dehydration alters the values of some laboratory parameters and affects prognosis as well. Therefore, parameters sensitive to hemoconcentration, such as albumin, cannot contribute much to the assessment of criticalness, but parameters reflecting dehydration can be considered. Body composition measurements may accurately assess nutritional state (6), but they are time-consuming and not generally available. Body weight in relation to height is perhaps one of the most practical markers to evaluate the severity of malnutrition in anorexia nervosa. Despite numerous reports of mortality from starvation, there are rather few in which height and weight are reported. To our knowledge, there have been 27 cases previously reported, who died of starvation and/or its related complications, with height and weight records. The data from these cases and the present case are summarized in Table 5. In almost all the cases, body weight was below $60 \%$ of standard. Henry (23) proposed that a body mass index $\left(\mathrm{BMI}, \mathrm{W} / \mathrm{Ht}^{2}\right)$ of 12 may be the absolute lower limit compatible with life. 
OKABE

Table 5. Clinical Data in Patients with Anorexia Nervosa Who Died of Starvation and/or Starvation-Related Complications

\begin{tabular}{|c|c|c|c|c|c|c|}
\hline Source, yr & $\begin{array}{l}\text { Age } \\
(\mathrm{yr})\end{array}$ & Sex & $\begin{array}{l}\text { Height } \\
(\mathrm{cm})\end{array}$ & $\begin{array}{c}\text { Lowest } \\
\text { body weight } \\
(\mathrm{kg})\end{array}$ & $\begin{array}{c}\text { Percentage } \\
\text { of standard } \\
\text { weight }\end{array}$ & Complications \\
\hline Stephens, 1895 (7) & 16 & $\mathrm{~F}$ & 162.6 & 22.2 & 38.3 & \\
\hline $\begin{array}{l}\text { Beck and Brøchner-Mortensen, } \\
1954 \text { (8) }\end{array}$ & 28 & $\mathrm{~F}$ & 167 & 25 & 41.2 & \\
\hline Miyazaki et al, 1968 (9) & 14 & $\mathrm{~F}$ & 150 & 24 & 47.6 & pulmonary hemorrhage \\
\hline Aoki, 1969 (10) & 16 & $\mathrm{~F}$ & 152 & 23 & 44.7 & gastric dilatation \\
\hline \multirow[t]{8}{*}{ Theander, 1970 (11) } & 31 & $\mathrm{~F}$ & 164 & 27 & 45.8 & infection \\
\hline & 40 & $\mathrm{~F}$ & 165 & 28 & 47.1 & \\
\hline & 20 & $\mathrm{~F}$ & 154 & 25 & 47.6 & \\
\hline & 30 & $\mathrm{~F}$ & 153 & 25 & 48.1 & $\begin{array}{l}\text { profuse bleeding } \\
\text { after teeth extraction }\end{array}$ \\
\hline & 21 & $\mathrm{~F}$ & 161 & 28 & 49.2 & \\
\hline & 21 & $\mathrm{~F}$ & 159 & 30 & 54.1 & \\
\hline & 28 & $\mathrm{~F}$ & 167 & 33 & 54.4 & \\
\hline & 32 & $\mathrm{~F}$ & 153 & 29 & 55.8 & \\
\hline Thoma, 1979 (12) & 17 & $\mathrm{~F}$ & 170 & 29 & 46.2 & \\
\hline \multirow[t]{2}{*}{ Hsu et al, 1979 (13) } & NI & $\mathrm{F}$ & NI & NI & $51^{*}$ & electrolyte disturbances \\
\hline & NI & $\mathrm{F}$ & NI & $\mathrm{NI}$ & $59^{*}$ & electrolyte disturbances \\
\hline Okuma and Araki, 1980 (14) & 14 & $\mathrm{~F}$ & 148 & 20 & 40.7 & acute hepatitis \\
\hline Mars et al, $1982(15)$ & 26 & $\mathrm{~F}$ & 152 & 27 & 52.4 & electrolyte disturbances \\
\hline Shishiba, 1983 (16) & 16 & $\mathrm{~F}$ & 152 & 23 & 44.7 & \\
\hline \multirow[t]{3}{*}{ Takagi et al, 1985 (17) } & 14 & $\mathrm{~F}$ & 156 & 25 & 46.6 & \\
\hline & 34 & $\mathrm{~F}$ & 152 & 25 & 48.5 & hypoglycemia \\
\hline & 22 & $\mathrm{M}$ & 180 & 44 & 59.3 & $\begin{array}{l}\text { pleural effusion, ascites } \\
\text { and edema }\end{array}$ \\
\hline Isner et al, 1985 (18) & 32 & $\mathrm{~F}$ & 165 & 23.5 & 39.5 & cardiac failure and pneumonia \\
\hline \multirow{2}{*}{$\begin{array}{l}\text { Negishi and Suematsu, } \\
1986 \text { (19) }\end{array}$} & 40 & $\mathrm{~F}$ & 150 & 19.5 & 38.7 & hypoglycemia \\
\hline & 17 & $\mathrm{~F}$ & 153 & 33 & 63.5 & gastric dilatation \\
\hline $\begin{array}{l}\text { Copeland and Herzog, } \\
1987(20)\end{array}$ & 26 & $\mathrm{~F}$ & 137.2 & 31.3 & 72.0 & hypoglycemia and pneumonia \\
\hline Chikasue et al, 1988 (21) & 37 & $\mathrm{~F}$ & 145 & 20.5 & 43.2 & \\
\hline Rich et al, 1990 (22) & 44 & F & 168 & 39 & 63.5 & hypoglycemia \\
\hline Present case & 16 & $\mathrm{~F}$ & 156 & 25 & 46.6 & \\
\hline
\end{tabular}

NI: No information was available, *Percentage of standard weight is calculated from matched population mean weight.

Although our sample number was small, many patients whose body weight was below $60 \%$ of standard (BMI was below 12.7 ) survived. Considering this result together with data from previous studies, we concluded that the risk of mortality may be quite low when body weight is above $60 \%$ of standard.

Gross muscle weakness was a prominent abnormality especially in cachectic patients in the present study. Sletteb $\varnothing$ and colleagues (24) and Shur et al (25) carried out muscle biopsies in weak anorectic patients. They found that both type 1 and type 2 , but predominantly type 2 fibers, were significantly reduced in size and there was no evidence of necrosis or inflammatory infiltrates. These findings suggest that the muscle weakness is due to a primary myopathic component. Although the exact mechanism of muscle changes remains uncertain, it appears likely that the muscular system is affected by a wasting process. Slettebø and colleagues (24) reported a trend of a decrease in muscle fiber size with decreasing BMI. This is compatible with the present findings of a trend that as weight loss advanced, the weaker patients became. We evaluated the weakness by asking the patients to sit up from the supine position, and they were then classified into three categories based on their ability. Some could sit up easily or by using their legs to propel their trunk upward; patients in this stage were considered to be at least temporarily free of danger. In the second stage, the patients could sit up only after rolling to their side; these patients usually sat up with head lag. In this stage, the patients were in danger of becoming terminally ill. In the third stage, the patients could not sit up at all. At this stage the patient's life was in danger and urgent nutritional support was mandatory. This method of appraisal was easy to apply in a clinical setting, and seemed to reflect physical decompensation well.

Orthostatic tachycardia was observed in many patients in the present study. It is known that heart rate frequently increases upon changing to an upright position in patients with hypovolemia, whereas blood pressure does not fall very much (26). Although there is wide variation in response, the tilt test gives us useful bedside information as to whether intravascular volume is reduced.

Duration of illness is another risk factor; those who lost weight in a short time should be carefully observed. 
Results of blood tests at the beginning of therapy may be misleading because of dehydration. Serum albumin and hemoglobin levels were further decreased a few weeks after admission, when the general condition had improved. Blood urea nitrogen level, however, may reflect the degree of dehydration. All nine patients whose BUN value exceeded $30 \mathrm{mg} / \mathrm{dl}$ had muscle weakness and/or orthostatic tachycardia, and four patients whose BUN value exceeded $45 \mathrm{mg} / \mathrm{dl}$ were at a critical stage. The high rates of BUN abnormalities seen in our sample may be explained by the fact that most of the patients had not received adequate medical care before admission. Although BUN value can easily be normalized by administration of intravenous fluids and nutritional supplements, high BUN may imply an acute danger to life. Serum electrolyte balance was maintained in most restrictive anorexics, even in those with dehydration. Electrolyte disturbances can develop in vomiting anorexics and cathartic and/or diuretic abusers. Hsu and associates (13) and Mars and colleagues (15) reported fatal cases of vomiting anorexics with severe electrolyte derangement. These patients, however, were also considerably emaciated, with body weight less than $60 \%$ of standard. Since the mortality rate of bulimics is quite low (27), death due to electrolyte disturbances among patients with anorexia nervosa seems unlikely to occur without malnutrition. Profound hypoglycemia is another complication of anorexia nervosa. Physicians should recognize that it may develop when there is increased glucose utilization, such as with infection (22) or when there is severe wasting, however, it is not possible to predict hypoglycemia using only the blood glucose level at the outset of therapy.

Isner et al (18) reported three cases of cardiac failure with QTc prolongation on electrocardiogram. In two of their cases, however, cardiac arrest occurred after hyperalimentation, and the other patient had used ipecac, which has not been sold in Japan. It is known that cardiac failure can occur during treatment of anorexia nervosa (28), in ipecac abusers (29), or liquidprotein dieters (30). In the present study, only two cases showed Q-Tc prolongation on electrocardiogram. Although electrocardiographic monitoring had better be conducted during the period of recovery from malnutrition in such patients, electrocardiography does not seem to be useful in assessing the criticalness in the acute phase.

Patient 7 died suddenly prior to performing thorough examinations such as electrocardiogram and the proximate cause of death remains unknown. It could not be excluded that hypoglycemia might have developed, although arrhythmia or electrolyte disturbance did not seem to be contributory because the pulse had been regular until the night before death and electrolytes were within normal limits 40 hours before death. One of the major differences between Patient 7 and the other cachectic patients in the present study was that insufficient fluid was administered in the acute stage. We failed to persuade her only of the advantage of enough fluid administration. Since anorectic patients are in a chronic state of malnutrition and/or loss of electrolytes, they are relatively tolerant of limited replacement. Although refeeding should be gradual and rapid compensation of electrolytes should be avoided to prevent cardiac failure and drastic changes in water and electrolyte balance $(28,31)$, sufficient fluid should be provided to maintain effective arterial blood volume for survival.

Finally, several findings of the present study may be tentative because of the limited sample, thus we need to accumulate a much larger number of cases. We hope that this paper will stimulate further study of emaciation in relation to the threat to life in anorexia nervosa.

\section{References}

1) Kreipe RE, Churchill BH, Strauss J. Long-term outcome of adolescents with anorexia nervosa. Am J Dis Child 143: 1322, 1989.

2) Theander S. Outcome and prognosis in anorexia nervosa and bulimia: Some results of previous investigations, compared with those of a Swedish long-term study. J Psychiatr Res 19: 493, 1985.

3) Schwartz DM, Thompson MG. Do anorectics get well? Current research and future needs. Am J Psychiatry 138: 319, 1981.

4) Jelliffe DB. The assessment of the nutritional status of the community. WHO Monogr 53: 238, 1966.

5) Buzby GP, Mullen JL, Matthews DC, et al. Prognostic nutritional index in gastrointestinal surgery. Am J Surg 139: 160, 1980.

6) Tellado JM, Garcia-Sabrido JL, Hanley JA, et al. Predicting mortality based on body composition analysis. Ann Surg 209: 81, 1989.

7) Stephens L. Case of anorexia nervosa. Necropsy. Lancet 1: 31, 1895.

8) Beck JC, Brøchner-Mortensen K. Observations on the prognosis in anorexia nervosa. Acta Med Scand 149: 409, 1954.

9) Miyazaki S, Yamaguchi M, Yamamura Y, et al. Anorexia nervosa with marrow hypoplasia. Shonika Shinryo 31: 1527, 1968 (in Japanese).

10) Aoki H. Anorexia nervosa. Jpn J Clin Exp Med 46: 1055, 1969 (in Japanese).

11) Theander S. Anorexia nervosa: A psychiatric investigation of 94 female patients. Acta Psychiatr Scand Suppl 214: 1970.

12) Thoma H. Clinical Survey of Thirty Cases. in: Anorexia Nervosa, Thoma H, Ed. International Universities Press, New York, 1979, p. 38.

13) Hsu LKG, Crisp AH, Harding B. Outcome of anorexia nervosa. Lancet 2: $61,1979$.

14) Okuma $\mathrm{H}$, Araki R. Case report of a girl who died from anorexia nervosa. Shinshin-Igaku 20: 249, 1980 (Abstract in English).

15) Mars DR, Anderson NH, Riggall FC. Anorexia nervosa: A disorder with severe acid-base derangements. South Med J 75: 1038, 1982.

16) Shishiba Y. A autopsy case of anorexia nervosa. Clinica 10: 676, 1983 (in Japanese).

17) Takagi S, Murata $Y$, Mitsumune $K$, et al. Death in anorexia nervosa. Seishin Igaku 27: 899, 1985 (in Japanese).

18) Isner JM, Roberts WC, Hymsfield SB, et al. Anorexia nervosa and sudden death. Ann Intern Med 102: 49, 1985.

19) Negishi K, Suematsu H. Autopsy cases of anorexia nervosa. ShinshinIgaku 26: 309, 1986 (Abstract in English).

20) Copeland PM, Herzog DB. Hypoglycemia and death in anorexia nervosa. Psychother Psychosom 48: 146, 1987.

21) Chikasue F, Kojima T, Miyazaki T, et al. A medicolegal case of anorexia nervosa. Hiroshima J Med Sci 37: 157, 1988.

22) Rich LM, Caine MR, Findling JW, et al. Hypoglycemic coma in anorexia nervosa: Case report and review of the literature. Arch Intern Med 150: $894,1990$.

23) Henry CJK. Body mass index and the limits of human survival. Eur J Clin Nutr 44: 329, 1990.

24) Slettebø M, Lindboe CF; Askevold F. The neuromuscular system in patients with anorexia nervosa: Electrophysiological and histologic studies. Clin Neuropathol 3: 217, 1984.

25) Shur E, Alloway R, Obrecht R, et al. Physical complications in anorexia nervosa: Haematological and neuromuscular changes in 12 patients. Br $\mathrm{J}$ Psychiatry 153: 72, 1988.

26) Knopp R, Claypool R, Leonardi D, et al. Use of the tilt test in measuring 


\section{OKABE}

acute blood loss. Ann Emerg Med 9: 72, 1980.

27) Herzog DB, Keller MB, Lavori PW. Outcome in anorexia nervosa and bulimia nervosa: A review of the literature. J Nerv Ment Dis 176: 131, 1988.

28) Powers PS. Heart failure during treatment of anorexia nervosa. Am J Psychiatry 139: 1167, 1982.

29) Romig RA. Anorexia nervosa, ipecac, and sudden death. Ann Intern Med 103: 641, 1985.
30) Isner JM, Sours HE, Paris AL, et al. Sudden, unexpected death in avid dieters using the liquid-modified-fast diet: Observations in 17 patients and the role of the prolonged QT interval. Circulation 60: 1401, 1979.

31) Suematsu H. Abnormal Findings and Recommendations in Anorexia Nervosa. in: Modern Clinical Points in Psychosomatic Medicine, Nakagawa T, Suematsu H, Eds. Kanehara Shuppan, Tokyo, 1992, p. 188 (in Japanese). 